\title{
Body shape throughout life and correlations with IGFs and GH
}

\author{
Eva S Schernhammer ${ }^{1,2,3}$, Shelley S Tworoger ${ }^{1,2}$, A Heather Eliassen ${ }^{1,2}$, Stacey \\ A Missmer ${ }^{1,2,4}$, Jeff M Holly, Michael N Pollak ${ }^{6}$ and Susan E Hankinson ${ }^{1,2}$
}

\author{
${ }^{1}$ Channing Laboratory, Department of Medicine, Harvard Medical School, Brigham and Women's Hospital, 181 Longwood Avenue, \\ Boston 02115, Massachusetts, USA \\ 2Department of Epidemiology, Harvard School of Public Health, Boston, Massachusetts, USA \\ ${ }^{3}$ LBI-ACR VIEnna and ACR-ITR VIEnna, Vienna, Austria \\ ${ }^{4}$ Department of Obstetrics, Gynecology and Reproductive Biology, Harvard Medical School, Brigham and Women's Hospital, \\ Boston, Massachusetts, USA \\ ${ }^{5}$ University Department of Clinical Science at North Bristol, Southmead Hospital, Bristol, UK \\ ${ }^{6}$ Departments of Medicine and Oncology, McGill University, Montréal, Québec, Canada \\ (Correspondence should be addressed to E S Schernhammer; Email: eva.schernhammer@channing.harvard.edu)
}

\begin{abstract}
Both insulin-like growth factors (IGF) and body size have been linked to premenopausal breast cancer risk. However, observational studies of IGF have not been consistent, and they suggest that perhaps earlier levels of IGF might be more strongly related to breast cancer than those measured at mid-age. We therefore sought to explore associations between several measures of body size throughout life and IGF levels in premenopausal women. We examined cross-sectional associations of birth weight, body shape (or somatotype) at ages 5 and 10, body mass index (BMI) at age 18 and adulthood, bra cup size at age 20, adult waist circumference and waist-to-hip ratio (WHR), and attained height with plasma levels of IGF-I, IGF binding protein 3 (IGFBP-3), IGFBP-1, and GH. Participants were 592 healthy premenopausal women aged 34-52 from the Nurses' Health Study II. Using multiple linear regression, we computed least-square mean hormone levels across the categories of early life anthropometric factors. We observed consistent and strong inverse associations between body shape at various stages in life and IGF levels. Somatotype at ages 5 and 10 was inversely associated with IGF-I ( $P$ for difference, $<0.01$ ) and positively with IGFBP-3 measured later in adulthood. Further, comparing women with a BMI $\geq 25 \mathrm{~kg} / \mathrm{m}^{2}$ at age $18 \mathrm{vs}<19 \mathrm{~kg} / \mathrm{m}^{2}$, similar associations were observed for IGF-I ( $P$ for trend, 0.005) and IGFBP-3 ( $P$ for trend, 0.01), which were even stronger for $\mathrm{BMl}$ at blood collection (BMI $<20$ versus $\mathrm{BMI} \geq 30$, mean IGF-I $254 \mathrm{ng} / \mathrm{ml}, 95 \% \mathrm{Cl}, 239-271$ vs $208 \mathrm{ng} / \mathrm{ml}, 95 \% \mathrm{Cl}, 195-222)$. Both waist circumference and WHR were strongly and inversely related to IGFBP-1 levels (top versus bottom quartile of waist circumference: $14.5 \mathrm{vs} 40.0 \mathrm{ng} / \mathrm{ml}, P$ for trend 0.0005 ; WHR: 18.3 vs $39.4 \mathrm{ng} / \mathrm{ml}, P$ for trend 0.002), with similar results for bra cup size at age 20 although they did not reach statistical significance. There was no association between height and IGF or GH levels. Birth weight, on the other hand, was weakly positively associated with both IGF-I and IGFBP-1 levels, and inversely with GH. Our results suggest that childhood and adult body size may affect premenopausal breast cancer risk differently than birth weight, through associations with IGF and GH levels.
\end{abstract}

Endocrine-Related Cancer (2007) 14 721-732

\section{Introduction}

The insulin-like growth factor (IGF) system is a complex system of ligands, receptors, and binding proteins. IGF-I and its prime regulator, growth hormone $(\mathrm{GH})$, are essential for normal growth. In fully developed organisms, together with the binding proteins of IGF-I, they play an important role in homeostasis and have been implicated in disease causation (most notably, carcinogenesis) as well as disease progression both early in life (Le Roith \& Butler 2005) as well as in adulthood (Pollak et al. 2004). Since the pulsatility of GH secretion would require frequent blood sampling, IGF-I, which has only minor circadian fluctuations (Minuto et al. 1981), is 
widely used in clinical and observational studies. The primary IGF-binding protein (IGFBP) is IGFBP-3.

IGF-I may increase premenopausal breast cancer risk, although associations between IGF-I and breast cancer risk have not been entirely consistent (Renehan et al. 2006). Earlier findings of strong positive associations between IGF-I and premenopausal breast cancer risk (Hankinson et al. 1998, Toniolo et al. 2000, Kaaks et al. 2002, Krajcik et al. 2002, Muti et al. 2002, Allen et al. 2005, Rinaldi et al. 2005, Schernhammer et al. 2005) have not been replicated in recent studies (Rinaldi et al. 2006, Schernhammer et al. 2006). Body size through out life, from birth weight (Ahlgren et al. 2003, McCormack et al. 2005, Vatten et al. 2005, Barba et al. 2006, Park et al. 2006) to adult body mass index (BMI; Carmichael \& Bates 2004), has been related to premenopausal breast cancer risk, although the direction of the associations changes (positive with birth weight and inverse with adult premenopausal $\mathrm{BMI}$ ), even after accounting for later BMI. Hence, we decided to evaluate associations between IGF and body size throughout life to assess if IGFs may play a role in the observed body size/breast cancer relationships. To test this hypothesis, we examined the cross-sectional associations of birth weight, body shape at ages 5 and $10, \mathrm{BMI}$ at age 18 and adulthood, bra cup size at age 20 , adult waist circumference and waist-to-hip ratio (WHR), as well as attained height in relation to IGF-I, IGFBP-3, IGFBP-1, and GH levels in 592 healthy premenopausal women enrolled in the Nurses' Health Study II (NHS II).

\section{Materials and methods}

\section{Study population}

The NHS II is a prospective cohort study that started in 1989, when 116609 registered female U.S. nurses aged 25-42 from 14 US states were enrolled. The NHS II was designed akin to the NHS, an earlier, independent cohort study of similar size which was initiated in 1976 (Colditz \& Hankinson 2005). The baseline questionnaire sought hormone use, reproductive history, current medication, history of disease, and a number of life-style factors. Since then, women have been followed biennially by mailed questionnaires, ascertaining any diagnosis of breast cancer, including date of diagnosis and updating exposures. Further details of the cohort have been published (Rockhill et al. 1998).

Women who had not previously reported a diagnosis of cancer were eligible for sample collections; in total, 29611 women in the NHS II cohort participated in our blood collection study from 1996 to 1999 . We provided blood collection kits and advised each participant to have blood samples drawn by a local laboratory or colleague. Premenopausal women not pregnant, breast feeding, or on hormone therapy were asked to provide two samples timed within their menstrual cycle. First samples were drawn in the follicular phase of the menstrual cycle; second samples were collected in the luteal phase. Samples were returned to our laboratory via overnight courier, with a frozen water sample to keep them cool. Of the 29611 participants, 18521 provided two timed blood samples, and 11090 women provided a single, untimed blood sample. A brief questionnaire was included with the blood kit, asking the specific date and time when blood samples were drawn, the first day of the nurse's current menstrual cycle, the number of hours since she had last eaten, her current weight, medication used, and any changes in her menstrual cycle characteristics. For women who gave both follicular and luteal samples, we used luteal samples in this study, because cyclic variations of IGF are only modest (Juul et al. 1997, Helle et al. 1998).

Women in this analysis were premenopausal controls who were matched to breast cancer cases diagnosed after blood collection and before June 2003 ( $n=479$; Tworoger et al. 2006), and a subset of women who provided three sets of timed follicular and luteal samples over $2-3$ years $(n=113)$. (We considered only the baseline samples for these women; Missmer et al. 2006). The study was approved by the Committee on the Use of Human Subjects in Research at the Brigham and Women's Hospital and the Harvard School of Public Health.

We defined menopausal status at the time of blood collection. Women who provided a timed sample were considered to be premenopausal. Women providing a single untimed sample were considered premenopausal if they a) reported that periods had not ceased or b) had a hysterectomy but had at least one ovary remaining and were $\leq 45$ (for nonsmokers) or $\leq 47$ (for smokers) years old-at these ages, fewer than $<10 \%$ of the cohort had had a natural menopause.

\section{Covariate information}

Information on exposure measures and potential covariates were asked on a questionnaire completed at blood collection and the biennial study questionnaires. In 1989, NHS II participants recalled their body fatness at ages 5 and 10, using a nine-level figure drawing (Baer et al. 2005) originally developed by Stunkard et al. (1983). The recall of body shape in childhood, among elderly women, was validated 
against weight and height measurements taken in childhood (Must et al. 1993). Oral contraceptive use, age at menarche, cycle regularity between ages 18 and 22 , weight at age 18 , and height were reported at baseline in 1989; oral contraceptive use was updated on subsequent biennial questionnaires. Birth weight was reported in 1991 and the participants were asked to choose one of the following categories: unknown, $<5.5,5.5-6.9,7.0-8.4,8.5-9.9$, or $10+$ pounds. Current weight and details about the blood collection date, time, and fasting status were reported on the blood questionnaire. BMI at age 18 and current BMI were calculated using adult height as weight in $\mathrm{kg}$ divided by height in meters squared. In 1993, women were asked to measure their waist and hip circumferences, to the nearest $1 / 4$ inch, if they had a tape measure easily available; $64 \%$ of women provided these measurements.

\section{Laboratory assays}

For IGFBP-1 analyses, only fasting blood samples were used. Total IGF-I, IGFBP-1, IGFBP-3, and GH levels were assayed by ELISA after acid extraction, using reagents from Diagnostic Systems Laboratory (Webster, TX, USA). Masked split specimens included within each batch were used to calculate the coefficient of variation within batches; for IGF-I, IGFBP-3, IGFBP-1, and GH, these were $6.8,4.2,1.6$, and $11.3 \%$ respectively.

\section{Statistical analysis}

For each of the biomarkers, we excluded women with missing values related to assay difficulties or low volume. We also identified statistical outliers based on the generalized extreme studentized deviate manyoutlier detection approach (Rosner 1993); one woman with an improbable IGFBP-1 concentration was identified as an outlier and excluded. In sum, a total of 592 healthy premenopausal controls ( 254 women in the IGFBP-1 analysis) formed the study population for the current analyses.

We used the natural logarithms of IGF-I, its binding proteins, and GH measurements in the analyses because the transformed values were more normally distributed. To test for differences in IGF levels by categories of covariates, we used mixed-effects regression models for clustered data to adjust for possible confounding due to other life style and reproductive factors (Zeger et al. 1988). Primary analyses calculated adjusted geometric means by category of exposure. Exposures consisted of birth weight $(<5.5,5.5-6.9,7.0-8.4,8.5+1 \mathrm{bs})$, somatotype at ages 5 and $10(1,2,3,4,5+)$, BMI at age $18\left(<19,19-<21,21-<23,23-<25,25+\mathrm{kg} / \mathrm{m}^{2}\right)$, BMI at blood collection $(<20,20-<22.5,22.5-<25$, $25-<27.5,27.5-<30,30+)$, and quartiles of waist circumference $(<60.5,60.5-<65.5,65.5-<72.6$, $72.6+\mathrm{cm})$, WHR $(<0.73,0.73-<0.77,0.77-<0.82$, $0.82+$ ), bra cup size (A or less, B, C, D or more), and height $(<139,139-<143,143-<147,147+\mathrm{cm})$. Tests for trend were conducted by modeling continuous, ln-transformed hormone levels (on continuous exposure measures) and calculating the Wald statistic (Hosmer \& Lemeshow 1989). In the analyses of birth weight and somatotype at ages 5 and 10, we excluded women born pre-term or as part of a multiple birth. Stratified analyses by age and BMI at blood draw used a multiplicative interaction term.

Multivariate models adjusted for assay batch $(1,2)$, age at blood draw $(<40,40-<45,45+$ years), fasting status (yes, no), time of day of blood draw (0100-0800 h, $0900 \mathrm{~h}$-noon, $1300 \mathrm{~h}$-midnight), month of blood draw (continuous), difference between luteal blood draw date and date of the next menstrual period (3-7, 8-21 days, other/unknown/untimed), and duration of past oral contraceptive use (never, $<4,4+$ years, missing). In addition, models with IGF-I or IGFBP-3 were mutually adjusted for each other. In analyses of waist circumference and WHR, we additionally adjusted for BMI (continuous). We also considered other potential confounders including simple hysterectomy, history of benign breast disease, family history of breast cancer, and parity; however, these did not change the results and therefore were not included in the final model.

Statistical analyses were performed with SAS software (SAS Institute, Cary, NC, USA). When the underlying variable was continuous, such as age or BMI, $P$ values were reported for the linear trend across categories. For categorical variables (such as smoking history or family history of cancer), the $P$ value reported represents the level of significance of the difference comparing extreme categories. All $P$ values were based on two-sided tests and were considered statistically significant if $\leq 0.05$.

\section{Results}

The 592 women who were available for analysis ranged in age from 34 to 52 years (median 43.5 years) at blood collection (Table 1). Eighty-six percent of women provided timed samples, and of those, $91.1 \%$ were ovulatory, setting progesterone values $>10 \mathrm{nmol} / \mathrm{l}$ for the acceptance of ovulation. Among women born fullterm, $3.3 \%$ weighed $<5.5$ pounds (equals $<2.5 \mathrm{~kg}$ ) at birth and $15.2 \%$ weighed $>8.5$ pounds (equals $>3.9 \mathrm{~kg}$ ). 
Table 1 Baseline characteristics of 592 women

\begin{tabular}{|c|c|c|}
\hline All women & Median & $\begin{array}{l}\text { Range (10th- } \\
\text { 90th percentile) }\end{array}$ \\
\hline Age (years) & 43.5 & $37.8-48.5$ \\
\hline BMI at blood draw & 23.8 & $19.9-32.1$ \\
\hline $\begin{array}{l}\text { Age at menarche } \\
\text { (years) }\end{array}$ & 12.0 & $11.0-14.0$ \\
\hline $\mathrm{BMI}$ at age 18 & 20.6 & $18.3-24.0$ \\
\hline $\begin{array}{l}\text { Waist circumference } \\
\text { (inches, 1986) }\end{array}$ & 65.5 & $57.2-82.0$ \\
\hline Waist-to-hip ratio (1986) & 0.77 & $0.70-0.87$ \\
\hline Height (inches) & 143.0 & $136.4-149.6$ \\
\hline Number of pregnancies ${ }^{a}$ & 2 & $1-3$ \\
\hline \multicolumn{3}{|l|}{ Plasma levels } \\
\hline IGF-I (ng/ml) & 245.4 & $146.5-347.9$ \\
\hline IGFBP-3 (ng/ml) & 4765 & $3297-5896$ \\
\hline IGFBP-1 (ng/ml) & 33.6 & $11.5-67.9$ \\
\hline $\mathrm{GH}(\mathrm{ng} / \mathrm{ml})$ & 0.24 & $0.14-4.14$ \\
\hline
\end{tabular}

\begin{tabular}{lr}
\hline & Percent \\
\hline Full-term pregnancies & 90.9 \\
Birth weight ${ }^{\mathrm{b}, \mathrm{c}}$ & \\
$\quad<5.5 \mathrm{Ibs}^{-5.9} \mathrm{lbs}$ & 3.3 \\
$5.5-6.9$ & 26.6 \\
$6.9-8.4 \mathrm{lbs}$ & 54.9 \\
$8.5+\mathrm{lbs}$ & 15.2 \\
Bra cup size at age 20 & \\
A or less & 32.9 \\
B & 44.4 \\
C & 18.4 \\
D & 4.3 \\
Somatotype at age $5^{\mathrm{c}}$ & \\
1 & 19.7 \\
2 & 31.7 \\
3 & 28.9 \\
4 & 13.1 \\
$5+$ & 6.6 \\
Somatotype at age $10^{\mathrm{C}}$ & \\
1 & 17.7 \\
2 & 30.0 \\
3 & 25.6 \\
4 & 16.8 \\
$5+$ & 9.9 \\
\hline
\end{tabular}

At natural menopause or bilateral oophorectomy.

${ }^{a}$ Among parous women only.

'Thirty women answered 'Don't know' to this question.

${ }^{\mathrm{c}}$ Among women $(n=538)$ who were born full-term.

Few women had a large body size at ages $5(6.6 \%)$ and 10 (9.9\%), and, on average, women had a considerably lower BMI at age 18 (median, $20.6 \mathrm{~kg} / \mathrm{m}^{2}$ ) than at blood collection (median, $23.8 \mathrm{~kg} / \mathrm{m}^{2}$ ). Birth weight among full-term babies was relatively weakly correlated with body shape at ages 5 and 10 (Spearman's $r=0.13$ and 0.14 respectively, both $P<0.01$ ), whereas body shape at ages 5 and 10 were strongly correlated with each other $(r=0.80, P<0.01)$. Levels of IGF-I, IGFBP-3, IGFBP-1, and $\mathrm{GH}$ were in the expected range for premenopausal women (Hankinson \& Schernhammer 2003, Renehan et al. 2004). The median values for IGF-I and IGFBP-3 were 245 and $4765 \mathrm{ng} / \mathrm{ml}$ respectively. Median values and their ranges for IGFBP-1 and GH along with information on other early life correlates are provided in Table 1.

In multivariate analyses, we observed a trend for higher IGF-I levels, lower IGFBP-3, and higher IGFBP-1 levels measured in adulthood in the babies that were born heavier ( $P$ for difference $0.20,0.11$, and 0.04 respectively) with a suggestion for higher $\mathrm{GH}$ levels in the leanest babies (Table 2). However, starting at age 5, this trend appeared to reverse, with consistently higher levels of adult IGF-I seen in the leanest girls and women, which persisted throughout adulthood. Specifically, at ages 5 and 10, girls with the heaviest stature had significantly lower adult IGF-I levels (age 5, $197 \mathrm{ng} / \mathrm{ml}$; 95\% CI, 176-219; age 10, $203 \mathrm{ng} / \mathrm{ml}$; 95\% CI, 186-221) than the leanest girls (age 5, $238 \mathrm{ng} / \mathrm{ml}$; 95\% CI, 226-250, $P$ for difference 0.003 ; at age $10,240 \mathrm{ng} / \mathrm{ml}$; $95 \% \mathrm{CI}, 228-253, P$ for difference $<0.001)$. These girls had higher adult IGFBP-3 levels and lower adult IGFBP-1 levels. Similarly, BMI at age 18 was a strong predictor of IGF levels: women with the highest BMI had a mean IGF-I level of 210, whereas the mean IGF-I level of the leanest women at age 18 was 239 ( $P$ for trend, 0.005 ); IGFBP-1 levels were also significantly lower in these women ( $P$ for trend, 0.01$)$. Finally, women with a BMI of $\geq 30$ at blood collection had mean IGF-I levels of $208 \mathrm{ng} / \mathrm{ml}$ (95\% CI, 195-222), compared with women with a BMI of less than 20 whose mean IGF-I level was $254 \mathrm{ng} / \mathrm{ml}$ (95\% CI, 239-271, $P$ for trend, <0.001), and their IGFBP-1 and GH levels were again significantly lower, whereas their IGFBP-3 levels were not significantly higher than those of the women with the lowest BMI.

Waist circumference and WHR were similarly related to IGF-I and IGFBP-3, but were particularly strong predictors of IGFBP-1 levels (top versus bottom quartile of waist circumference: $14.5 \mathrm{vs} 40.0 \mathrm{ng} / \mathrm{ml}, P$ for trend 0.0005 ; WHR: 18.3 vs $39.4 \mathrm{ng} / \mathrm{ml}, P$ for trend 0.002 ).

Current BMI (as assessed at blood draw) was strongly correlated with BMI at age 18 (Spearman's $r=0.54, P<0.001)$ and to a lesser degree also with early somatotypes (somatotype at age $5, r=0.24$; age $10, r=0.30, P<0.001)$. We therefore adjusted for current BMI in secondary analyses and results remained largely unchanged. Specifically, there was still a strong inverse trend between early somatotypes and IGF-I levels as well as between WHR and waist circumference and IGFBP-1 levels, and a positive association between birth weight and IGFBP-1 levels 


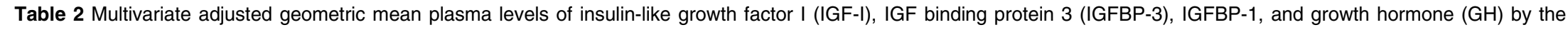
categories of anthropometric correlates $^{a}$

\begin{tabular}{|c|c|c|c|c|c|c|}
\hline & \multirow[b]{2}{*}{ Category definition } & \multirow[b]{2}{*}{$N$} & \multicolumn{4}{|c|}{ Geometric means, $95 \% \mathrm{Cl}$} \\
\hline & & & $\mid G F-I^{b}$ & IGFBP-3 ${ }^{b}$ & IGFBP-1 ${ }^{\mathrm{C}}$ & $\mathrm{GH}^{\mathrm{d}}$ \\
\hline \multirow[t]{5}{*}{ Birth weight (pounds) ${ }^{e}$} & $<5.5$ & 17 & $218(190-249)$ & $4821(4493-5173)$ & $23.2(15.4-34.9)$ & $0.78(0.42-1.48)$ \\
\hline & $5.5-6.9$ & 135 & $228(217-241)$ & $4632(4496-4771)$ & $31.8(26.1-38.7)$ & $0.43(0.34-0.55)$ \\
\hline & $7.0-8.4$ & 279 & $233(226-241)$ & $4538(4450-4628)$ & $28.7(25.4-32.5)$ & $0.50(0.42-0.59)$ \\
\hline & $\geq 8.5$ & 77 & $239(227-251)$ & $4516(4348-4690)$ & $35.9(29.1-44.4)$ & $0.50(0.36-0.68)$ \\
\hline & $P$ for difference & 508 & 0.21 & 0.11 & 0.04 & 0.21 \\
\hline \multirow[t]{6}{*}{ Somatotype at age $5^{\mathrm{e}}$} & 1 & 105 & 238 (226-250) & $4524(4371-4683)$ & $31.2(25.4-38.3)$ & $0.47(0.35-0.63)$ \\
\hline & 2 & 169 & $236(227-246)$ & 4499 (4379-4623) & $28.4(23.7-34.1)$ & $0.57(0.46-0.72)$ \\
\hline & 3 & 154 & $243(233-253)$ & 4506 (4392-4622) & $32.4(27.9-37.6)$ & $0.43(0.34-0.54)$ \\
\hline & 4 & 70 & $211(197-225)$ & $4821(4642-5006)$ & $28.6(22.9-35.6)$ & $0.50(0.35-0.70)$ \\
\hline & $5+$ & 35 & $197(176-219)$ & $4762(4555-4978)$ & $33.2(24.6-44.7)$ & $0.59(0.36-0.95)$ \\
\hline & $P$ for difference & 533 & 0.002 & 0.08 & 0.74 & 0.43 \\
\hline \multirow[t]{6}{*}{ Somatotype at age $10^{\mathrm{e}}$} & 1 & 95 & $240(228-253)$ & $4580(4421-4744)$ & $33.1(27.4-40.0)$ & $0.47(0.35-0.64)$ \\
\hline & 2 & 161 & 241 (231-252) & 4515 (4394-4640) & $28.2(23.5-33.9)$ & $0.48(0.38-0.59)$ \\
\hline & 3 & 137 & 239 (228-250) & 4457 (4342-4576) & $33.6(29.0-38.8)$ & $0.47(0.37-0.60)$ \\
\hline & 4 & 90 & 219 (207-233) & 4678 (4527-4835) & $29.1(22.8-37.2)$ & $0.60(0.43-0.84)$ \\
\hline & $5+$ & 53 & $203(186-221)$ & 4804 (4598-5020) & 23.5 (18.4-29.9) & $0.52(0.35-0.77)$ \\
\hline & $P$ for difference & 536 & $<0.001$ & 0.10 & 0.03 & 0.70 \\
\hline \multirow[t]{6}{*}{ BMI at age $18\left(\mathrm{~kg} / \mathrm{m}^{2}\right)$} & $<19$ & 117 & 239 (227-250) & 4581 (4464-4701) & $33.8(28.2-40.6)$ & $0.45(0.35-0.58)$ \\
\hline & $19-20.9$ & 221 & $239(231-248)$ & 4516 (4421-4612) & $32.7(28.8-37.1)$ & $0.46(0.38-0.56)$ \\
\hline & $21-22.9$ & 156 & 235 (225-245) & 4541 (4415-4671) & $29.4(24.7-35.1)$ & $0.54(0.43-0.68)$ \\
\hline & $23-24.9$ & 60 & $205(187-225)$ & 4676 (4484-4877) & $22.3(16.6-29.9)$ & $0.64(0.43-0.94)$ \\
\hline & $\geq 25$ & 37 & 210 (192-229) & $4780(4506-5070)$ & $24.0(17.7-32.5)$ & $0.39(0.25-0.60)$ \\
\hline & $P$ for trend & 591 & 0.005 & 0.81 & 0.01 & 0.79 \\
\hline \multirow[t]{5}{*}{ Bra cup size at age 20} & A or less & 189 & 241 (233-249) & 4562 (4467-4658) & $31.5(27.5-36.1)$ & $0.49(0.40-0.61)$ \\
\hline & B & 255 & 230 (222-239) & 4598 (4504-4693) & $31.6(28.0-35.6)$ & $0.52(0.44-0.62)$ \\
\hline & $\mathrm{C}$ & 106 & 227 (214-240) & $4520(4367-4679)$ & $27.1(21.7-34.0)$ & $0.48(0.36-0.63)$ \\
\hline & D or more & 25 & 220 (192-252) & 4549 (4237-4885) & $21.5(14.8-31.4)$ & $0.41(0.24-0.70)$ \\
\hline & $P$ for difference & 575 & 0.21 & 0.94 & 0.06 & 0.53 \\
\hline \multirow[t]{7}{*}{ BMl at blood draw $\left(\mathrm{kg} / \mathrm{m}^{2}\right)$} & $<20$ & 62 & $254(239-271)$ & 4444 (4270-4625) & $50.7(41.6-61.7)$ & $0.51(0.34-0.77)$ \\
\hline & $20-22.4$ & 156 & 235 (226-245) & $4522(4410-4636)$ & $41.1(36.3-46.5)$ & $0.57(0.46-0.72)$ \\
\hline & $22.5-24.9$ & 142 & $236(226-245)$ & $4462(4348-4580)$ & $32.9(28.0-38.7)$ & $0.55(0.43-0.72)$ \\
\hline & $25-27.4$ & 88 & $244(230-259)$ & $4578(4397-4767)$ & $25.4(21.6-29.9)$ & $0.45(0.34-0.59)$ \\
\hline & 27.5-29.9 & 50 & 216 (197-238) & $4638(4421-4868)$ & $18.4(14.2-23.9)$ & $0.51(0.35-0.73)$ \\
\hline & $\geq 30$ & 90 & 208 (195-222) & 4848 (4704-4996) & 16.5 (13.4-20.3) & $0.32(0.26-0.40)$ \\
\hline & $P$ for trend & 588 & $<0.001$ & 0.23 & $<0.001$ & 0.004 \\
\hline
\end{tabular}




\begin{tabular}{|c|c|c|c|c|c|c|}
\hline & \multirow[b]{2}{*}{ Category definition } & \multirow[b]{2}{*}{$N$} & \multicolumn{4}{|c|}{ Geometric means, $95 \% \mathrm{Cl}$} \\
\hline & & & $I G F-I^{b}$ & IGFBP-3 ${ }^{b}$ & IGFBP- $1^{c}$ & $\mathrm{GH}^{\mathrm{d}}$ \\
\hline \multirow[t]{5}{*}{ Waist circumference ${ }^{f}$} & Q1 & 95 & $238(225-252)$ & $4560(4407-4717)$ & $40.0(34.8-48.3)$ & $0.62(0.45-0.85)$ \\
\hline & Q2 & 99 & 241 (229-255) & $4452(4302-4608)$ & $34.5(29.3-40.5)$ & $0.56(0.42-0.75)$ \\
\hline & Q3 & 84 & $239(227-253)$ & $4481(4311-4657)$ & $31.6(27.0-37.1)$ & $0.55(0.39-0.76)$ \\
\hline & Q4 & 103 & $222(210-235)$ & 4757 (4621-4898) & $14.5(12.1-17.4)$ & $0.37(0.29-0.48)$ \\
\hline & $P$ for trend & 381 & 0.66 & 0.19 & 0.0005 & 0.13 \\
\hline \multirow[t]{5}{*}{ Waist-to-hip ratio ${ }^{f}$} & Q1 & 89 & $243(230-256)$ & $4538(4381-4700)$ & $39.4(33.2-46.8)$ & $0.67(0.48-0.93)$ \\
\hline & Q2 & 97 & $229(217-242)$ & 4565 (4413-4723) & $30.5(25.4-36.6)$ & $0.53(0.40-0.69)$ \\
\hline & Q3 & 93 & $243(229-258)$ & $4490(4335-4650)$ & $30.7(25.1-37.6)$ & $0.46(0.34-0.63)$ \\
\hline & Q4 & 101 & $227(215-240)$ & $4658(4507-4813)$ & $18.3(14.7-22.7)$ & $0.44(0.33-0.58)$ \\
\hline & $P$ for trend & 380 & 0.57 & 0.77 & 0.002 & 0.16 \\
\hline \multirow[t]{5}{*}{ Height (1976) } & Q1 & 100 & 231 (219-244) & $4616(4466-4772)$ & $31.6(27.0-36.9)$ & $0.54(0.40-0.71)$ \\
\hline & Q2 & 162 & 225 (215-237) & $4626(4501-4755)$ & $27.8(23.4-33.0)$ & $0.48(0.39-0.60)$ \\
\hline & Q3 & 158 & 239 (230-249) & 4557 (4451-4666) & $31.6(26.9-37.2)$ & $0.46(0.38-0.57)$ \\
\hline & Q4 & 172 & $234(224-244)$ & 4495 (4391-4601) & $30.7(26.4-35.7)$ & $0.50(0.40-0.63)$ \\
\hline & $P$ for trend & 592 & 0.96 & 0.41 & 0.35 & 0.86 \\
\hline
\end{tabular}

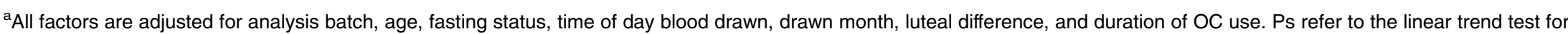
ordinal variables (e.g., age, BMI, height) and a test of difference between extreme categories for non-ordinal variables (e.g., somatotype $=1$ vs $5+$ )

${ }^{\mathrm{b}}$ Models are mutually adjusted for IGF-I/IGFBP-3.

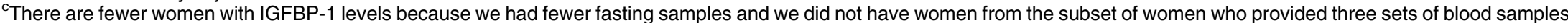
over 2-3 years.

${ }^{\mathrm{d}}$ There are fewer women with $\mathrm{GH}$ because we did not have women from the subset of women who provided three sets of blood samples over 2-3 years.

${ }^{\text {e}}$ Among women $(n=538)$ who were born full-term.

Waist-to-hip ratio and waist circumference were assessed in 1986. 
(data not shown). Similarly in these models, the associations between plasma levels and current BMI were unchanged. In stratified analyses (age, BMI, and parity), we observed no noteworthy differences.

In secondary analyses with IGF-I and IGFBP-1, we additionally adjusted for current milk consumption and circulating insulin levels, respectively. In these analyses, the inverse associations between current BMI, waist circumference, and WHR and IGFBP-1 levels remained virtually unchanged (data not shown). Simultaneous adjustment for BMI and insulin also did not alter these estimates substantially.

\section{Discussion}

In one of the most comprehensive studies to date to explore associations between several indicators of body shape throughout a woman's life and premenopausal levels of IGF and GH, we found that weight at birth was weakly positively associated with adult IGF-I and IGFBP-1 levels, whereas indicators of heavier weight, as measured throughout childhood and at later age (though before menopause), were strongly inversely associated with adult IGF-I and IGFBP-1 levels. Our findings are in line with positive associations between birth weight and inverse associations between body fatness at young ages and adult BMI and premenopausal breast cancer risk, implying that the IGF axis might be one possible mechanism for these associations.

Birth weight, a surrogate for in utero hormone exposure, has been directly associated with an increased breast cancer risk (Okasha et al. 2002). When assessed simultaneously, circulating IGF-I levels are positively correlated with birth weight and other parameters of size at birth (Ong et al. 2000, Christou et al. 2001, Vatten et al. 2002, Boyne et al. 2003) and there are some suggestions that IGF-I and other members of the IGF family play important roles in intrauterine growth (Lo et al. 2002, Boyne et al. 2003). Polymorphisms in the IGF-I gene have previously been associated both with postnatal weight gain (Vaessen et al. 2002) and with low birth weight in a small for gestational age population (Johnston et al. 2003), suggesting that it affects fetal growth. Lower birth weight has been associated with higher circulating IGF-I levels in several studies of children (Fall et al. 1995, Ong et al. 2002). Generally, the most prominent explanation offered for an inverse association between birth weight and childhood IGF-I suggests that it is caused by decreased nutritional availability to the fetus, which, in turn, leads to reprogramming of the IGF axis resulting in increased levels of circulating IGF-I after birth among children experiencing a postnatal catch-up growth. Yet data on associations between birth weight and plasma markers of the GH-IGF axis in adulthood are sparse and have produced equivocal results. Inverse (37), positive (40) and null (42) associations between birth weight and IGF-I levels have been reported in young adult women (Jernstrom \& Olsson 1998). In the few studies on middle-aged (similar to ours; Holt et al. 2004, Johnsen et al. 2004) and older (Kajantie et al. 2003) women, no association was found between birth weight and IGF-I levels, although several studies were smaller than ours $(38,41)$ and not all the studies were able to exclude preterm births in their analysis (39). Given that our results are not significantly positive and the two other studies are null--although an association cannot be ruled out--it seems unlikely that a strong relation exists between birth weight and mid-adult IGF-I.

Even fewer studies have explored associations between birth weight and GH and IGFBP-1 levels. Flanagan et al. (1999) reported that low birth weight was associated with reduced urinary GH production as assessed at age 20-21, whereas there was no such association in another, more carefully conducted albeit small study (Fall et al. 1998). One study associated birth weight positively with IGFBP-1 levels in older age (Kajantie et al. 2003), which is in line with our findings. Similarly, in the only other study (Kistner et al. 2004) among 50 young adult women, IGFBP-1 levels were lower in adult women born full-term but small for gestational age - yet, a correlation with birth weight was not reported.

Although height is strongly correlated with IGF-I levels in children (Juul et al. 1994b), the weight of evidence, including that from our study, suggests no important correlation between height and IGF levels in adulthood (Signorello et al. 2000, Suga et al. 2001, Vaessen et al. 2001, Helle et al. 2002, Teramukai et al. 2002).

Associations between body shape and circulating IGF are complex and remain poorly understood. For example, if assessed simultaneously, adiposity has not been related to plasma IGF-I levels in childhood or adolescence (Juul et al. 1994a) in the largest study, to date (877 children and adolescents), whereas a positive association between IGF-I and weight (independent of height) was noted among children aged 4 and 7 in another fairly large study ( $n=444$; Fall et al. 1995). Other reports also support the fact that levels of IGF-I measured in childhood are positively associated with childhood adiposity (Fall et al. 2000, Ong et al. 2002) and with childhood nutrition (Hoppe et al. 2004, Rogers et al. 2005). The same nutritional exposures in childhood however have the opposite effect on IGF-I 
levels measured much later in adulthood (Elias et al. 2004, Ben-Shlomo et al. 2005). Consistent with our own findings, an inverse association between BMI at age 7 and adult IGF-I levels was reported among 394 Finnish men and women by Kajantie et al. (2003), with two additional reports supporting inverse associations of adiposity measured in childhood and IGF-I levels measured later in adult life (Kajantie et al. 2003, Martin et al. 2006). These studies and the current findings would be compatible with increased nutrition in childhood, resulting in both an increase in adiposity and an increase in hepatic IGF-I production. The latter then acts via pituitary feedback to suppress GH output with a long-term resetting of the GH/IGF-I axis into adulthood and consequently lower adult IGF-I levels. Evidence like that gathered from a small study showing premenopausal IGF-I levels to be related to an elevated breast cancer risk, but primarily in the youngest premenopausal and oldest postmenopausal group in that study (Rollison et al. 2006), further indicate that the effect if IGF itself may vary throughout life.

When both parameters are assessed in adulthood, studies tend to support an inverse association between the measures of body shape and IGF-I (Landin-Wilhelmsen et al. 1994), similar to our findings, although not all studies have found the association to be linear. For example, one of the largest studies to date (Ben-Shlomo et al. 2003) reported inverse associations between adult (age 25, $n=951$ ) BMI and IGF-I levels. In a recent detailed evaluation among healthy women, BMI was also, albeit weakly, associated with a lower IGF-I/ IGFBP-3 ratio (Holmes et al. 2001). In two large studies of predominantly Caucasian women, BMI and IGF levels were weakly associated with extreme BMI, on both ends of the spectrum (Holmes et al. 2001, Lukanova et al. 2002). This has been confirmed in the largest study to date ( $n=2139$ women), which reports of lower IGF-I levels in the leanest women $\left(\mathrm{BMI} \leq 22.5 \mathrm{~kg} / \mathrm{m}^{2}\right)$ and those with a $\mathrm{BMI}>29.2$ compared with women with a BMI inside this range (Gram et al. 2006, Pischon et al. 2006). A study of older women, on the other hand, demonstrated weak to no associations (Goodman-Gruen \& Barrett-Connor 1997) and a more detailed evaluation of these data showed a stronger positive association between WHR (Jernstrom \& Barrett-Connor 1999) and IGF-I levels in these women (age range 53-90), indicating that the relationship between BMI and IGF levels may shift again in postmenopausal women. Current BMI and IGFBP-1 have consistently been inversely associated in several studies (Janssen et al. 1998, Heald et al. 2001, Kajantie et al. 2003). Studies on associations between WHR or waist circumference and IGF levels have been scarce to date (Holmes et al. 2001, Johansson et al. 2004, Bezemer et al. 2005), and they do not support an association. No studies, to our knowledge, have evaluated the associations of bra cup size with the IGF axis; our findings suggest no important association exists.

As a possible explanation for our findings, it is conceivable that larger body shapes at ages 5 and 10 as well as a higher BMI at age 18 are simply reflections of reduced body growth during adolescence, as growth velocity is linked to GH/IGF-I levels. Thus, the lower IGF-I levels in women with a high adult BMI may have caused slower growth and induced a higher body mass, since it is conceivable that they had lower IGF-I levels already early on in their life. This is further supported by reports of strong correlations between GH and IGF-I and height in prepubertal children and adolescents $(r=0.65$ and 0.78 respectively; Blum et al. 1993), further assuming that children who grow fast and are taller also tend to be leaner as well. Alternatively, it is conceivable that obesity in children enhances their response to $\mathrm{GH}$, which in turn may lead to higher IGF-I levels, as suggested by a recent study (Bouhours-Nouet et al. 2007). Finally, twin studies (Kao et al. 1994, Harrela et al. 1996) have shown about half of the interindividual variability in circulating IGF-I and IGFBP-3 levels to be genetically determined.

The strengths of our study include its fairly large size and extensive information on early life correlates collected over more than 15 years. A limitation of our study is its cross-sectional nature, which makes it hard to predict whether factors associated with IGF levels determine those levels, or are in fact determined by them. The one-timed assessment of plasma IGF and, in particular, GH levels represents another potential limitation, as non-differential measurement error may have led to an underestimation of true associations. Finally, while ethnic differences in the relationship between circulating IGF and obesity are likely to exist (Henderson et al. 2006), we were unable to address these in our sample of mostly Caucasian women.

In summary, our data suggest that childhood and adult body size may affect premenopausal breast cancer risk differently than birth weight, at least in part through associations with IGF and GH levels. They may also have important implications for other chronic diseases such as cardiovascular disease and type II diabetes.

\section{Acknowledgements}

This research was supported by National Cancer Institute (NCI) Grants CA67262 and CA50385 and by the NCI Specialized Program of Research Excellence (SPORE) in breast cancer at the Channing Laboratory. Dr Pollak was partially supported by 
grants from the Translational Acceleration Program of the Canadian Breast Cancer Research Alliance. Dr Eliassen was supported by Cancer Education and Career Development Grant R25 CA 098566-2 from the National Cancer Institute. We are indebted to the participants of the ongoing NHS II for their continuing outstanding dedication to the study. We would like to express our thanks for the valuable input and insights of Drs Graham Colditz, David Hunter (Project Director of the NHSII cohort) and Walter Willett (Principal Investigator of the NHSII). We are also indebted to Helena Ellis, Ellen Hertzmark, and Victor Pontes for their technical assistance. No authors have declared a financial interest in a company whose product was studied in the work presented in this paper.

\section{References}

Ahlgren M, Sorensen T, Wohlfahrt J, Haflidadottir A, Holst C \& Melbye M 2003 Birth weight and risk of breast cancer in a cohort of 106,504 women. International Journal of Cancer 107 997-1000.

Allen NE, Roddam AW, Allen DS, Fentiman IS, Dos Santos Silva I, Peto J, Holly JM \& Key TJ 2005 A prospective study of serum insulin-like growth factor-I (IGF-I), IGFII, IGF-binding protein-3 and breast cancer risk. British Journal of Cancer 92 1283-1287.

Baer HJ, Colditz GA, Rosner B, Michels KB, Rich-Edwards JW, Hunter DJ \& Willett WC 2005 Body fatness during childhood and adolescence and incidence of breast cancer in premenopausal women: a Prospective Cohort Study. Breast Cancer Research 7 R314-R325.

Barba M, McCann SE, Nie J, Vito D, Stranges S, Fuhrman B, Trevisan M, Muti P \& Freudenheim JL 2006 Perinatal exposures and breast cancer risk in the Western New York Exposures and Breast Cancer (WEB) Study. Cancer Causes and Control 17 395-401.

Ben-Shlomo Y, Holly J, McCarthy A, Savage P, Davies D, Gunnell D \& Davey Smith G 2003 An investigation of fetal, postnatal and childhood growth with insulin-like growth factor I and binding protein 3 in adulthood. Clinical Endocrinology 59 366-373.

Ben-Shlomo Y, Holly J, McCarthy A, Savage P, Davies D \& Davey Smith G 2005 Prenatal and postnatal milk supplementation and adult insulin-like growth factor I: long-term follow-up of a randomized controlled trial. Cancer Epidemiology, Biomarkers and Prevention 14 1336-1339.

Bezemer ID, Rinaldi S, Dossus L, Gils CH, Peeters PH, Noord PA, Bueno-de-Mesquita HB, Johnsen SP, Overvad K, Olsen A et al. 2005 C-peptide, IGF-I, sex-steroid hormones and adiposity: a cross-sectional study in healthy women within the European prospective investigation into cancer and nutrition (EPIC). Cancer Causes and Control 16 561-572. Blum WF, Albertsson-Wikland K, Rosberg S \& Ranke MB 1993 Serum levels of insulin-like growth factor I (IGF-I) and IGF binding protein 3 reflect spontaneous growth hormone secretion. Journal of Clinical Endocrinology and Metabolism. 76 1610-1616.

Bouhours-Nouet N, Gatelais F, Boux de Casson F, Rouleau S \& Coutant R 2007 The insulin-like growth factor-I response to growth hormone is increased in prepubertal children with obesity and tall stature. Journal of Clinical Endocrinology and Metabolism 92 629-635.

Boyne MS, Thame M, Bennett FI, Osmond C, Miell JP \& Forrester TE 2003 The relationship among circulating insulin-like growth factor (IGF)-I, IGF-binding proteins-1 and -2, and birth anthropometry: a Prospective Study. Journal of Clinical Endocrinology and Metabolism $\mathbf{8 8}$ 1687-1691.

Carmichael AR \& Bates T 2004 Obesity and breast cancer: a review of the literature. Breast 13 85-92.

Christou H, Connors JM, Hatzidakis V, Papathanassoglou E, Ringer SA \& Mantzoros CS 2001 Cord blood leptin and insulin-like growth factor levels are independent predictors of fetal growth. Journal of Clinical Endocrinology and Metabolism 86 935-938.

Colditz GA \& Hankinson SE 2005 The Nurses' Health Study: lifestyle and health among women. Nature Reviews Cancer 5 388-396.

Elias SG, Keinan-Boker L, Peeters PH, Van Gils CH, Kaaks R, Grobbee DE \& Van Noord PA 2004 Long term consequences of the 1944-1945 Dutch famine on the insulin-like growth factor axis. International Journal of Cancer 108 628-630.

Fall CH, Pandit AN, Law CM, Yajnik CS, Clark PM, Breier B, Osmond C, Shiell AW, Gluckman PD \& Barker DJ 1995 Size at birth and plasma insulin-like growth factor-1 concentrations. Archives of Disease in Childhood 73 287-293.

Fall C, Hindmarsh P, Dennison E, Kellingray S, Barker D \& Cooper C 1998 Programming of growth hormone secretion and bone mineral density in elderly men: a hypothesis. Journal of Clinical Endocrinology and Metabolism 83 135-139.

Fall PM, Clark PC, Hindmarsh PE, Clayton AW \& Shiell CM 2000 Urinary GH and IGF-I excretion in nine year-old children: relation to sex, current size and size at birth. Clinical Endocrinology 53 69-76.

Flanagan VM, Moore IF, Godsland RA, Cockington JS \& Robinson DI 1999 Reduced foetal growth and growth hormone secretion in adult life. Clinical Endocrinology 50 735-740.

Goodman-Gruen D \& Barrett-Connor E 1997 Epidemiology of insulin-like growth factor-I in elderly men and women. The Rancho Bernardo Study. American Journal of Epidemiology 145 970-976.

Gram IT, Norat T, Rinaldi S, Dossus L, Lukanova A, Tehard B, Clavel-Chapelon F, van Gils CH, van Noord PA, Peeters PH et al. 2006 Body mass index, waist circumference and waist-hip ratio and serum levels of IGF-I and IGFBP-3 in European women. International Journal of Obesity 30 1623-1631. 
Hankinson SE \& Schernhammer ES 2003 Insulin-like growth factor and breast cancer risk: evidence from observational studies. Breast Disease 17 27-40.

Hankinson SE, Willett WC, Colditz GA, Hunter DJ, Michaud DS, Deroo B, Rosner B, Speizer FE \& Pollak M 1998 Circulating concentrations of insulin-like growth factor-I and risk of breast cancer. Lancet 351 1393-1396.

Harrela M, Koistinen H, Kaprio J, Lehtovirta M, Tuomilehto J, Eriksson J, Toivanen L, Koskenvuo M, Leinonen P, Koistinen R \& Seppälä M 1996 Genetic and environmental components of interindividual variation in circulating levels of IGF-I, IGF-II, IGFBP-1, and IGFBP-3. Journal of Clinical Investigation 98 2612-2615.

Heald AH, Cruickshank JK, Riste LK, Cade JE, Anderson S, Greenhalgh A, Sampayo J, Taylor W, Fraser W, White A et al. 2001 Close relation of fasting insulin-like growth factor binding protein-1 (IGFBP-1) with glucose tolerance and cardiovascular risk in two populations. Diabetologia 44 333-339.

Helle SI, Anker GB, Meadows KA, Holly JM \& Lonning PE 1998 Alterations in the insulin-like growth factor system during the menstrual cycle in normal women. Maturitas 28 259-265.

Helle SI, Ekse D, Holly JM \& Lonning PE 2002 The IGFsystem in healthy pre- and postmenopausal women: relations to demographic variables and sex-steroids. Journal of Steroid Biochemistry 81 95-102.

Henderson KD, Goran MI, Kolonel LN, Henderson BE \& Le Marchand L 2006 Ethnic disparity in the relationship between obesity and plasma insulin-like growth factors: the multiethnic cohort. Cancer Epidemiology Biomarkers and Prevention 15 2298-2302.

Holmes MD, Pollak MN \& Hankinson SE 2001 Lifestyle correlates of plasma insulin-like growth factor I and insulin-like factor binding protein 3 concentrations. Cancer Epidemiology, Biomarkers and Prevention 11 862-867.

Holt RI, Syddall HE, Phillips DI, Martyn CN, Gluckman PD, Breier BH, Wood PJ \& Fall CH 2004 Serum insulin-like growth factor-I concentrations in late middle age: no association with birthweight in three UK cohorts. Acta Physiologica Scandinavica 180 359-366.

Hoppe C, Udam TR, Lauritzen L, Molgaard C, Juul A \& Michaelsen KF 2004 Animal protein intake, serum insulin-like growth factor I, and growth in healthy $2.5-y-$ old Danish children. American Journal of Clinical Nutrition 80 447-452.

Hosmer DW \& Lemeshow S 1989 Applied Logistic Regression. New York: John Wiley \& Sons.

Janssen JA, Stolk RP, Pols HA, Grobbee DE \& Lamberts SW 1998 Serum total IGF-I, free IGF-I, and IGFB-1 levels in an elderly population: relation to cardiovascular risk factors and disease. Arteriosclerosis, Thrombosis, and Vascular Biology 18 277-282.

Jernstrom H \& Barrett-Connor E 1999 Obesity, weight change, fasting insulin, proinsulin, C-peptide, and insulin-like growth factor-1 levels in women with and without breast cancer: the Rancho Bernardo Study. Journal of Women's Health and Gender-Based Medicine 8 1265-1272.

Jernstrom H \& Olsson H 1998 Insulin-like growth factor-1 in relation to adult weight and birth weight in healthy nulliparous women. International Journal of Gynaecology and Obstetrics 62 11-18.

Johansson H, Baglietto L, Guerrieri-Gonzaga A, Bonanni B, Mariette F, Macis D, Serrano D, Sandri MT \& Decensi A 2004 Factors associated with circulating levels of insulin-like growth factor-I and insulin-like growth factor binding protein-3 in 740 women at risk for breast cancer. Breast Cancer Research and Treatment 88 63-73.

Johnsen SP, Sorensen HT, Thomsen JL, Sorensen HT, Thomsen JL, Gronbaek H, Flyvbjerg A, Engberg M \& Lauritzen T 2004 Markers of fetal growth and serum levels of insulin-like growth factor (IGF) I, -II and IGF binding protein 3 in adults. European Journal of Epidemiology 19 41-47.

Johnston LB, Dahlgren J, Leger J, Gelander L, Savage MO, Czernichow P, Wikland KA \& Clark AJ 2003 Association between insulin-like growth factor I (IGF-I) polymorphisms, circulating IGF-I, and pre- and postnatal growth in two European small for gestational age populations. Journal of Clinical Endocrinology and Metabolism $\mathbf{8 8}$ 4805-4810.

Juul A, Bang P, Hertel NT, Main K, Dalgaard P, Jorgensen K, Muller J, Hall K \& Skakkebaek NE 1994a Serum insulinlike growth factor-I in 1030 healthy children, adolescents, and adults: relation to age, sex, stage of puberty, testicular size, and body mass index. Journal of Clinical Endocrinology and Metabolism 78 744-752.

Juul A, Main K, Blum WF, Lindholm J, Ranke MB \& Skakkebaek NE 1994b The ratio between serum levels of insulin-like growth factor (IGF)-I and the IGF binding proteins (IGFBP-1, 2 and 3) decreases with age in healthy adults and is increased in acromegalic patients. Clinical Endocrinology 41 85-93.

Juul A, Scheike T, Pedersen AT, Main KM, Andersson AM , Pedersen LM \& Skakkebaek NE 1997 Changes in serum concentrations of growth hormone, insulin, insulin-like growth factor and insulin-like growth factorbinding proteins 1 and 3 and urinary growth hormone excretion during the menstrual cycle. Human Reproduction 12 2123-2128.

Kaaks R, Lundin E, Rinaldi S, Manjer J, Biessy C, Soderberg S, Lenner P, Janzon L, Riboli E, Berglund G et al. 2002 Prospective study of IGF-I, IGF-binding proteins, and breast cancer risk, in northern and southern Sweden. Cancer Causes and Control 13 307-316.

Kajantie E, Fall CH, Seppala M, Koistinen R, Dunkel L, Yliharsila H, Osmond C, Andersson S, Barker DJ, Forsen T et al. 2003 Serum insulin-like growth factor (IGF)-I and IGF-binding protein-1 in elderly people: relationships with cardiovascular risk factors, body 
composition, size at birth, and childhood growth. Journal of Clinical Endocrinology and Metabolism $\mathbf{8 8}$ 1059-1065.

Kao PC, Matheny APJ \& Lang CA 1994 Insulin-like growth factor-I comparisons in healthy twin children. Journal of Clinical Endocrinology and Metabolism 78 310-312.

Kistner A, Jacobson SH, Celsi G, Vanpee M \& Brismar K 2004 IGFBP-1 levels in adult women born small for gestational age suggest insulin resistance in spite of normal BMI. Journal of Internal Medicine 255 82-88.

Krajcik RA, Borofsky ND, Massardo S \& Orentreich N 2002 Insulin-like growth factor (IGF-I), IGF-binding proteins, and breast cancer. Cancer Epidemiology, Biomarkers and Prevention 11 1566-1573.

Landin-Wilhelmsen K, Wilhelmsen L, Lappas G, Rosen T, Lindstedt G, Lundberg PA \& Bengtsson BA 1994 Serum insulin-like growth factor I in a random population sample of men and women: relation to age, sex, smoking habits, coffee consumption and physical activity, blood pressure and concentrations of plasma lipids, fibrinogen, parathyroid hormone and osteocalcin. Clinical Endocrinology 41 351-357.

Lo HC, Tsao LY, Hsu WY, Chen HN, Yu WK \& Chi CY 2002 Relation of cord serum levels of growth hormone, insulin-like growth factors, insulin-like growth factor binding proteins, leptin, and interleukin- 6 with birth weight, birth length, and head circumference in term and preterm neonates. Nutrition 18 604-608.

Lukanova A, Soderberg S, Stattin P, Palmqvist R, Lundin E, Biessy C, Rinaldi S, Riboli E, Hallmans G \& Kaaks R 2002 Nonlinear relationship of insulin-like growth factor (IGF)-I and IGF-I/IGF-binding protein-3 ratio with indices of adiposity and plasma insulin concentrations (Sweden). Cancer Causes and Control 13 509-516.

Martin RM, Holly JM, Davey Smith G \& Gunnell D 2006 Associations of adiposity from childhood into adulthood with insulin resistance and the insulin-like growth factor system: 65-year follow-up of the boyd orr cohort. Journal of Clinical Endocrinology and Metabolism 91 3287-3295.

McCormack VA, dos Santos Silva I, Koupil I, Leon DA \& Lithell HO 2005 Birth characteristics and adult cancer incidence: Swedish cohort of over 11,000 men and women. International Journal of Cancer 115 611-617.

Minuto F, Underwood LE, Grimaldi P, Furlanetto RW, Van Wyk JJ \& Giordano G 1981 Decreased serum somatomedin $\mathrm{C}$ concentrations during sleep: temporal relationship to the nocturnal surges of growth hormone and prolactin. Journal of Clinical Endocrinology and Metabolism 52 399-403.

Missmer SA, Bertone-Johnson ER, Spiegelman D, Barbieri RL, Pollak M \& Hankinson SE 2006 Reproducibility of plasma hormone and growth factor levels among premenopausal women over a 2-3 year period. Cancer Epidemiology, Biomarkers and Prevention 15 972-978.

Must A, Willett WC \& Dietz WH 1993 Remote recall of childhood height, weight, and body build by elderly subjects. American Journal of Epidemiology 138 56-64.
Muti P, Quattrin T, Grant BJB, Krogh V, Micheli A, Schuenemann HJ, Ram M, Freudenheim JL, Sieri S, Trevisan M et al. 2002 Fasting glucose is a risk factor for breast cancer: a Prospective Study. Cancer Epidemiology, Biomarkers and Prevention 11 1361-1368.

Okasha M, Gunnell D, Holly J \& Davey Smith G 2002 Childhood growth and adult cancer. Best Practice \& Research. Clinical Obstetrics and Gynaecology 16 225-241.

Ong K, Kratzsch J, Kiess W, Costello M, Scott C \& Dunger D 2000 Size at birth and cord blood levels of insulin, insulin-like growth factor I (IGF-I), IGF-II, IGF-binding protein-1 (IGFBP-1), IGFBP-3, and the soluble IGF-II/mannose-6phosphate receptor in term human infants. The ALSPAC Study Team. Avon Longitudinal Study of Pregnancy and Childhood. Journal of Clinical Endocrinology and Metabolism 85 4266-4269.

Ong K, Kratzsch J, Kiess W \& Dunger D 2002 Circulating IGF-I levels in childhood are related to both current body composition and early postnatal growth rate. Journal of Clinical Endocrinology and Metabolism 87 1041-1044.

Park SK, Garcia-Closas M, Lissowska J, Sherman ME, McGlynn KA, Peponska B, Bardin-Mikoajczak A, Zatonski W, Szeszenia-Dabrowska N \& Brinton LA 2006 Intrauterine environment and breast cancer risk in a Population-Based Case-Control Study in Poland. International Journal of Cancer 119 2136-2141.

Pischon T, Lahmann PH, Boeing H, Friedenreich C, Norat T, Tjonneland A, Halkjaer J, Overvad K, Clavel-Chapelon F, Boutron-Ruault MC et al. 2006 Body size and risk of colon and rectal cancer in the European prospective investigation into cancer and nutrition (EPIC). Journal of National Cancer Institute 98 920-931.

Pollak MN, Schernhammer ES \& Hankinson SE 2004 Insulin-like growth factors and neoplasia. Nature Reviews Cancer 47 505-518.

Renehan AG, Zwahlen M, Minder C, O'Dwyer ST, Shalet SM \& Egger M 2004 Insulin-like growth factor (IGF)-I, IGF binding protein-3, and cancer risk: systematic review and meta-regression analysis. Lancet $\mathbf{3 6 3}$ 1346-1353.

Renehan AG, Harvie M \& Howell A 2006 Insulin-like growth factor (IGF)-I, IGF binding protein-3, and breast cancer risk: eight years on. Endocrine-Related Cancer 13 273-278.

Rinaldi S, Kaaks R, Zeleniuch-Jacquotte A, Arslan AA, Shore RE, Koenig KL, Dossus L, Riboli E, Stattin P, Lukanova A et al. 2005 Insulin-like growth factor-I, IGF binding protein3 , and breast cancer in young women: a comparison of risk estimates using different peptide assays. Cancer Epidemiology, Biomarkers and Prevention 14 48-52.

Rinaldi S, Peeters PH, Berrino F, Dossus L, Biessy C, Olsen A, Tjonneland A, Overvad K, Clavel-Chapelon F, Boutron-Ruault MC et al. 2006 IGF-I, IGFBP-3 and breast cancer risk in women: the european prospective investigation into cancer and nutrition (EPIC). EndocrineRelated Cancer 13 593-605. 
Rockhill B, Willett WC, Hunter DJ, Manson JE, Hankinson SE, Spiegelman D \& Colditz GA 1998 Physical activity and breast cancer risk in a cohort of young women. Journal of National Cancer Institute 90 1155-1160.

Rogers IS, Gunnell D, Emmett PM, Glynn LR, Dunger DB \& Holly JM 2005 Cross-sectional associations of diet and insulin-like growth factor levels in 7- to 8-year-old children. Cancer Epidemiology, Biomarkers and Prevention 14 204-212.

Le Roith D \& Butler AA 2005 Insulin-like growth factors in pediatric health and disease. Journal of Clinical Endocrinology and Metabolism 84 4355-4361.

Rollison DE, Newschaffer CJ, Tao Y, Pollak M \& Helzlsouer KJ 2006 Premenopausal levels of circulating insulin-like growth factor I and the risk of postmenopausal breast cancer. International Journal of Cancer 118 1279-1284.

Rosner B 1993 Fundamentals of Biostatistics. Belmont: Wadsworth.

Schernhammer ES, Holly JM, Pollak MN \& Hankinson SE 2005 Circulating levels of insulin-like growth factors, their binding proteins, and breast cancer risk. Cancer Epidemiology, Biomarkers and Prevention 14 699-704.

Schernhammer ES, Holly JM, Hunter DJ, Pollak MN \& Hankinson SE 2006 Insulin-like growth factor-I, its binding proteins (IGFBP-1 and IGFBP-3), and growth hormone and breast cancer risk in the Nurses Health Study II. Endocrine-Related Cancer 13 583-592.

Signorello LB, Kuper H, Lagiou P, Wuu J, Mucci LA, Trichopoulos D \& Adami HO 2000 Lifestyle factors and insulin-like growth factor 1 levels among elderly men. European Journal of Cancer Prevention 9 173-178.

Stunkard AJ, Sorensen T \& Schulsinger F 1983 Use of the Danish adoption register for the study of obesity and thinness. In The Genetics of Neurological and Psychiatric Disorders, pp 115-120. Eds SS Kety, LP Rowland, SW Sidman \& SW Mathysee. New York: Raven Press.

Suga K, Imai K, Eguchi H, Hayashi S, Higashi Y \& Nakachi K 2001 Molecular significance of excess body weight in postmenopausal breast cancer patients, in relation to expression of insulin-like growth factor I receptor and insulin-like growth factor II genes. Japanese Journal of Cancer Research 92 127-134.

Teramukai S, Rohan T, Eguchi H, Oda T, Shinchi K \& Kono S 2002 Anthropometric and behavioral correlates of insulin-like growth factor I and insulin-like growth factor binding protein 3 in middle-aged Japanese men. American Journal of Epidemiology 156 344-348.

Toniolo P, Bruning PF, Akhmedkhanov A, Bonfrer JM, Koenig KL, Lukanova A, Shore RE \& ZeleniuchJacquotte A 2000 Serum insulin-like growth factor-I and breast cancer. International Journal of Cancer $\mathbf{8 8}$ 828-832.

Tworoger SS, Sluss P \& Hankinson SE 2006 Association between plasma prolactin concentrations and risk of breast cancer among predominately premenopausal women. Cancer Research 66 2476-2482.

Vaessen N, Heutink P, Janssen JA, Witteman JC, Testers L, Hofman A, Lamberts SW, Oostra BA, Pols HA \& van Duijn CM 2001 A polymorphism in the gene for IGF-I: functional properties and risk for type 2 diabetes and myocardial infarction. Diabetes 50 637-642.

Vaessen N, Janssen JA, Heutink P, Hofman A, Lamberts SW, Oostra BA, Pols HA \& van Duijn CM 2002 Association between genetic variation in the gene for insulin-like growth factor-I and low birthweight. Lancet 359 1036-1037.

Vatten LJ, Nilsen ST, Odegard RA, Romundstad PR \& Austgulen R 2002 Insulin-like growth factor I and leptin in umbilical cord plasma and infant birth size at term. Pediatric Cardiology 109 1131-1135.

Vatten LJ, Nilsen TI, Nilsen S, Trichopoulos D \& Romundstad PR 2005 Size at birth and risk of breast cancer: prospective population-based study. International Journal of Cancer 114 461-464.

Zeger SL, Liang KY \& Albert PS 1988 Models for longitudinal data: a generalized estimating equation approach. Biometrics 44 1049-1060. 